\title{
KUALITAS HIDUP PENDERITA KANKER PAYUDARA ( CA MAMAE ) DI POLI ONKOLOGI RSU DR. PIRNGADI MEDAN
}

\author{
Quality of Life of Breast Cancer Patients (Ca Mamae) \\ in poly oncology dr. Pirngadi Hospital Medan
}

\author{
Evamona Sinuraya \\ Dosen Tetap Yayasan Akper Kesdam I/BB Medan \\ email : evamona_anaksintua@yahoo.co.id
}

\begin{abstract}
Abstrak
Periode setelah penentuan diagnosa seseorang menderita kanker payudara adalah saat- saat yang menakutkan bagi kebanyakan perempuan. Vonis menderita kanker payudara, memyebabkan pikiran mereka tertuju kepada kematian, dan hal inilah salah satu yang memicu depresi sehingga mempengaruhi kualitas hidup penderita kanker payudara.

Tujuan penelitian ini untuk menganalisis kualitas hidup penderita kanker payudara. Penelitian ini merupakan penelitian kualitatif dengan pendekatan fenomenologi. Penelitian dilakukan di RSUD dr. Pirnagdi Medan. Informan dalam penelitian ini sebanyak 8 orang (4 informan utama, 4 informan pendukung). Analisis data dilakukan secara kualitatif dengan menyusun secara sistematis data yang diperoleh dari hasil wawancara.

Hasil penelitian menunjukkan bahwa kesehatan fisik penderita kanker payudara menurun karena merasakan nyeri, berdenyut denyut pada daerah payudara, mengalami kebas, kehilangan payudara setelah dilakukan operasi atau pengangkatan. Beban psikologis semakin berat dirasakan penderita kanker payudarasetelah divonis kanker payudara. Perasaan sedih, cemas, takut, kecewa, marah pada Tuhan, putus asa, hilang percaya diri, malu, stress dan depresi menyebabkan pasien ingin bunuh diri. Hubungan sosial dengan masyarakat sekitar tetap dijaga dengan baik oleh penderita kanker payudara dengan tetap mengikuti kegiatankegiatan dimasyarakat. Lingkungan yang tidak nyaman kurang memberikan rasa aman bagi penderita kanker payudara semakin meningkatkan stress penderita. Kekurangan finansial untuk biaya pengobatan menambah beban bagi penderita kanker payudara. Dukungan sosial diperoleh penderita kanker payudaradari orang orang terdekatnya seperti adik, anak dan suami. Dukungan orang-orang terdekat membuat penderita menjadi lebih kuatmenjalani hidup dan mempunyai harapan yang lebih baikpada masa yang akan datang.

Disarankan kepada keluarga (suami, anak, adik, dan lain-lain) tetap memberi dukungan dalam bentuk apapun yang nantinya dapat membuat penderita kanker payudara tersebut merasa kuat dan kualitas hidup meningkat.
\end{abstract}

Kata kunci : Kualitas hidup, Kanker payudara

\begin{abstract}
The period after the determination of a person suffering from breast cancer diagnosisis a frigteningmoment for most women. The verdict had breast cancer, causing their minds drawn to death, and this is one of thetriggers of depression that affect the quality of life of breast cancer patients.

The purpose of this study was to analyze the qualityof life of breast cancer patients. This study is a qualitative reseach with phenomenological approach. The study was conducted in dr. Pirngadi Medan. Informantsin this study as many as 8 people ( 4 man informan, 4 informan supporters). The data were analyzed qualitatively by systematically compile data obtained from interviews.

The results showed that the physical health of patients with breast cancer declines because of pain, throbbingin the breast area, experiencing numbness, loss of breast after surgery or removal. Increasingly heavy psychological burden felt by patients with breast cancer after breast cancer convicted. Feelings of sadness, anxiety, fear, disappoinment, anger at God, despair, loss of confidence, embarrasment, stress and depression, causing the patient to commit suicide, social relationships with surrounding communities remain well guardedby breast cancer, to keep activities in the community. Less uncomfortable environment to provide security for patient with breast cancer further increase stress sufferers. Financial shortage to increase the burden of the cost of treatment for patients with breast cancer. Social suppot is obtained with breast cancer from the closest people as a brother, son and husband. The support of those closest to making the patient becomes stronger through life and have a better hope in the future.

Suggested to the family ( husband, son, brother, etc ) continue to provide support in any from that will be able to make the breast cancer patients feel strong and quality of life improved.
\end{abstract}

Keywords : Quality of Life, Breast Cancer

\section{Pendahuluan}

Masalah yang sering dihadapi oleh wanita

adalah masalah kesehatan reproduksi. Definisi kesehatan reproduksi wanita adalah sebagai keadaan kesejahteraan fisik, mental, sosial yang utuh dalam segala hal yang berkaitan dengan 
sistem, fungsi-fungsi dan proses reproduksi. Wanita memang sangat rawan akan bahaya bagian reproduksinya. Kesehatan alat reproduksi pada wanita sebagai jaminan akan kualitas organ vital serta kesehatan pribadinya. Dengan alat reproduksi yang sehat maka kualitas sel telur pun juga berpengaruh besar untuk menghasilkan keturunan. Beberapa kesehatan reproduksi dikarenakan masalah-masalah yang tidak diduga karena beberapa wanita kurang menjaga kebersihan reproduksi. Salah satu penyakit yang sering dikeluhkan menyerang kesehatan reproduksi wanita dan menakutkan adalah kanker.

Kanker merupakan suatu kondisi di mana sel telah mengalami kehilangan pengendalian dan mekanisme normalnya sehingga mengalami pertumbuhan yang tidak normal, cepat dan tidak terkendali. Kanker menjadi salah satu penyebab utama kematian global, berdasarkan data yang dirilis International Agency for Research on Cancer salah satu lembaga di bawah Badan Kesehatan Dunia Perserikatan Bangsa-Bangsa (PBB).

Menurut temuan World Health Organization's International Agency for Research on Cancer (IARC), angka kematian global akibat kanker meningkat menjadi 8,2 juta pada tahun 2012. Di samping itu, peneliti juga menemukan penderita kanker payudara (ca mammae) meningkat tajam, hal tersebut menunjukkan bahwa kanker payudara sebagai penyakit yang penyebarannya terus meluas di seluruh dunia. Kematian akibat kanker payudara naik $8 \%$ dari 7,6 juta pada survei sebelumnya di tahun 2011 dan mengakibatkan meninggalnya 522.000 penderita kanker payudara tahun 2012, naik $14 \%$ pada periode yang sama.

Pada tahun 2006 di Amerika Serikat, terdapat 212.920 kasus baru kanker payudara pada wanita dan 1.720 kasus baru pada pria, dengan 40.970 kasus kematian pada wanita dan 460 kasus kematian pada pria. Di Indonesia, kanker payudara menempati urutan pertama dari semua jenis kanker. Kejadian kanker payudara di Indonesia sebesar $11 \%$ dari seluruh kejadian kanker. Sekitar 70 persen pasien kanker payudara datang ke rumah sakit berada pada kondisi stadium lanjut. Menurut Miller, sebanyak $16 \%-25 \%$ pasien menderita kanker sekaligus mengalami depresi.

Berdasarkan data Sistem Informasi Rumah Sakit (SIRS) tahun 2012, kanker payudara menempati urutan pertama pada pasien rawat inap di seluruh RS di Indonesia (16,85\%), disusul kanker leher rahim (11,78\%). Faktor risiko yang menyebabkan tingginya kejadian kanker di Indonesia yaitu prevalensi merokok 23,7\%, obesitas umum penduduk berusia 15 tahun pada laki-laki $13,9 \%$ dan pada perempuan $23,8 \%$. Prevalensi kurang konsumsi buah dan sayur 93,6\%, konsumsi makanan diawetkan 6,3\%, makanan berlemak 12,8\%, dan makanan dengan penyedap $77,8 \%$, prevalensi kurang aktivitas fisik sebesar $48,2 \%$.

Data yang diperoleh dari Rekam Medik (medical record) Rumah Sakit Umum dr. Pirngadi Medan bahwa penderita kanker payudara ( $c a$ mammae) pada tahun 2013 sebanyak 1.366 orang. Pada tahun 2014 (periode Januari - Juni 2014) jumlah penderita kanker payudara sebanyak 704 orang. Jumlah tersebut diperkirakan akan terus meningkat sampai dengan bulan Desember 2014.

Sebagai tolak ukur keberhasilan pengobatan kanker, termasuk kanker payudara, biasanya adalah ketahanan hidup 5 tahun (5 year survival). Vadya dan Shukla menyatakan bahwa faktor-faktor yang mempengaruhi prognosis dan ketahanan hidup penderita kanker payudara adalah besar tumor, status kelenjar getah bening regional, skin oedema 'pembengkakan kulit', status menopause, perkembangan sel tumor, residual tumor burden (tumor sisa), jenis patologinya, dan metastase, terapi, serta reseptor estrogen. Selain itu, ditambahkan pula dengan umur dan besar payudara. Azis FM dkk. menyatakan bahwa ketahanan hidup penderita kanker dipengaruhi oleh pengobatan, ukuran tumor, jenis histologi, ada tidaknya invasi ke pembuluh darah, anemia, dan penyulit seperti hipertensi.

Kanker payudara adalah pertumbuhan sel payudara yang tidak terkontrol dan membentuk neoplasma yang jahat dan jika tidak ditahan atau dicegah pertumbuhannya dapat menyebabkan kematian. Selain karena resiko akan kematian, ada beberapa hal menarik yang menjadi penyebab munculnya reaksi pada perempuan akibat menderita kanker payudara. Penyebab yang pertama adalah operasi pengambilan jaringan kanker sampai pengangkatan payudara. Hal ini terkait dengan suatu asumsi bahwa seorang perempuan adalah makhluk yang unik dan indah. Keindahan itu tentunya tidak lepas dari bentuk tubuh ideal yang diidam-idamkan oleh setiap perempuan. Bentuk tubuh ideal ini seringkali dikait-kaitkan dengan bentuk payudara yang indah dan ideal pula.

Lebih lanjut Jamison dalam Wijayanti ${ }^{7}$ mengatakan bahwa periode setelah penentuan diagnosis bahwa seseorang menderita kanker adalah saat-saat yang menakutkan bagi kebanyakan perempuan. Ketakutan yang sering muncul adalah bayangan bahwa usianya akan singkat sehingga tidak dapat melakukan hal-hal yang menjadi keinginannya, ketakutan bahwa dirinya tidak akan menarik lagi dan ketakutan bahwa dirinya tidak dapat berperan sebagai istri yang akan memberikan kebahagiaan bagi sang suami (psikoseksual), dan sebagainya. Adanya ketakutan yaitu bahwa dirinya yang tidak menarik lagi dan tidak dapat berperan sebagai istri yang akan memberikan kebahagiaan ini, tentu saja terkait dengan penurunan bentuk 
tubuh yang muncul akibat penyakit kanker payudara. Selain 2 hal tersebut penyebab munculnya reaksi yang ketiga adalah rasa nyeri yang sangat hebat yang dirasakan para perempuan penderita kanker payudara dan gejala sakit fisik yang lain seperti mual, muntah, anoreksia (yang sifatnya subyektif namun dapat memberikan dampak negatif pada penurunan gejala fisik seperti keringat berlebihan, pucat, dan salivasi) dan obstruksi usus (tidak mau makan dan minum karena lambungnya mengalami sakit yang sangat hebat).

Penderita kanker termasuk kanker payudara, tekanan psikologis seperti sedih, rasa putus asa, malu, kecemasan dan depresi sangatlah mungkin untuk dialami mengingat belum banyaknya informasi yang diketahui masyarakat tentang kanker payudara, sehingga saat seseorang divonis menderita kanker, pikiran mereka akan tertuju kepada kematian yang menghantui mereka, dan hal inilah salah satu yang memicu depresi. Pasien penderita kanker payudara membutuhkan bantuan dukungan sosial untuk tetap berpikir positif akan keadaan dirinya sehingga mampu menurunkan kecemasan, depresi dan ketidakberdayaan.

Pasien kanker sangat membutuhkan seseorang yang bisa memahami emosinya, ketakutan, kecemasan serta bertukar informasi tentang perawatan dan pengobatan yang akan, sedang ataupun sudah dijalaninya. Keperluan tersebut dapat dipenuhi dari aspek dukungan yang diberikan oleh komunitas sosial. Dukungan sosial bisa dilakukan oleh anggota keluarga, rekan, masyarakat, kalangan profesional ataupun sukarelawan yang berfungsi sebagai pendamping bagi pasien kanker. Pendekatan dukungan sosial sangat diperlukan dalam usaha melawan kanker, meningkatkan sikap menghargai diri sendiri pada pasien. Bukti-bukti dari hasil penelitian yang pernah dilakukan menunjukkan pendekatan dukungan sosial dapat menjadi penentu bagi perkembangan kesehatan. Bagi pasien kanker, dukungan sosial merupakan dorongan untuk melawan kanker (fighting spirit) dan lebih membantu pasien untuk bertahan. Analisis korelasi menunjukkan semakin besar dukungan sosial yang diperoleh, maka semakin rendah ketegangan psikologi yang dirasakan. Selain itu, pasien yang memperoleh dukungan sosial yang tinggi, menunjukkan penyesuaian yang lebih baik.

Sarafino dalam Sari mengatakan bahwa ada empat jenis dukungan sosial yaitu: dukungan emosional (emotional support), dukungan penghargaan (esteem support), dukungan instrumental atau dukungan yang sifatnya nyata (instrumental or tangible support), dan dukungan informasi (informational support).

Survei pendahuluan yang peneliti lakukan pada tanggal 14-26 Juli 2014 di Poli Onkologi
Rumah Sakit Umum dr. Pirngadi Medan bahwa jumlah penderita kanker payudara (ca mammae) sebanyak 31 orang. Untuk mengetahui dukungan sosial keluarga pada penderita kanker payudara, peneliti mewawancarai 15 orang penderita kanker payudara dengan menanyakan bagaimana dukungan sosial keluarga setelah diketahui atau didiagnosis menderita kanker payudara oleh dokter. Jawaban yang diperoleh dari penderita beragam, ada yang mengatakan bahwa keluarga terutama suami menunjukkan perubahan sikap yang negatif terhadap penderita, hal itu dibuktikan bahwa penderita datang sendiri ke Rumah Sakit Umum dr. Pirngadi Medan, keluarga tidak memberikan motivasi atau semangat pada penderita untuk berobat dan berupaya mengobati penyakitnya, keluarga tidak memberikan informasi yang tepat tentang penyakit kanker payudara dan pengobatannya, bahkan ada 2 orang penderita yang diceraikan oleh suaminya setelah mengetahui menderita kanker payudara, ada juga penderita yang mengatakan bahwa keluarganya biasa-biasa saja tidak memberikan dukungan tetapi juga tidak menjauhi. Tetapi sebaliknya, ada juga beberapa penderita kanker payudara yang mendapatkan dukungan (support) dari suami ataupun anggota keluarga lainnya, bahkan melebihi dukungan sebelum diketahui menderita kanker payudara.

\section{Metode}

Penelitian ini menggunakan metode kualitatif dengan paradigma interpretif. Metode kualitatif mengungkapkan berbagai keunikan yang terdapat dalam individu, kelompok dan masyarakat atau organisasi dalam kehidupan sehari-hari secara menyeluruh, terperinci dan dalam. Penelitian kualitatif dengan paradigma interpretif (naturalistik) adalah penelitian melihat suatu fenomena atau kejadian secara alamiah, bukan oleh manipulasi peneliti, dan melihat suatu fenomena atau kejadian tidak cukup hanya melihat sesuatu yang nyata tetapi juga perlu melihat sesuatu yang nyata tersebut. Paradigma interpretif memusatkan penyelidikan terhadap cara manusia memaknai kehidupan sosial dan bagaimana manusia mengeskpresikan pemahamannya.

Paradigma interpretif menekankan peneliti harus memahami realitas sosial dari berbagai sudut pandang orang yang hidup di dalamnya. Di dalam penelitian kualitatif menekankan bahwa peneliti berfungsi sebagai instrumen kunci dimana peneliti sebagai alat pengumpul data dan semakin tinggi pengetahuan dan wawasan peneliti maka akan semakin banyak dan luas data yang didapatkan.

\section{Hasil}

Informan utama dalam penelitian ini yang bersedia berpartisipasi diperoleh sebanyak 4 orang (Ny. E.S., Ny. S.S., Ny. N.P, Ny. T.T). Seluruh 
informan pertama kali ditemui di Poli Onkologi Rumah Sakit Umum Daerah dr. Pirngadi Medan sedang melakukan kunjungan. Seluruh informan bersedia menandatangani informed consent yang disediakan.

\section{Karakteristik Informan Penelitian}

No Keterangan Informan Informan 2

\begin{tabular}{|c|c|c|c|}
\hline A. & $\begin{array}{l}\text { Informan } \\
\text { Utama }\end{array}$ & & \\
\hline 1. & Inisial & Ny. E.S & Ny. T.T \\
\hline 2. & Umur saat ini & 41 tahun & 53 tahun \\
\hline 3. & $\begin{array}{l}\text { Umur saat } \\
\text { menikah }\end{array}$ & - & 19 tahun \\
\hline 4. & $\begin{array}{l}\text { Pendidikan } \\
\text { terakhir }\end{array}$ & SMA & SMA \\
\hline 5. & Suku & Batak & Batak \\
\hline 6. & Agama & Protestan & Protestan \\
\hline 7. & Jumlah Anak & - & 4 orang \\
\hline 8. & Pekerjaan & $\begin{array}{l}\text { Berjualan } \\
\text { baju bekas }\end{array}$ & $\begin{array}{l}\text { Berjualan } \\
\text { baju bekas }\end{array}$ \\
\hline 9. & $\begin{array}{l}\text { Status } \\
\text { Perkawinan }\end{array}$ & $\begin{array}{l}\text { Belum } \\
\text { menikah }\end{array}$ & $\begin{array}{l}\text { Menikah } \\
\text { (pisah } \\
\text { ranjang) }\end{array}$ \\
\hline
\end{tabular}

\section{Pembahasan \\ Kualitas Hidup Penderita Kanker Payudara (Ca Mammae)}

\section{Kesehatan Fisik}

Payudara merupakan salah satu dari pada ciri-ciri seks sekunder yang memiliki arti penting bagi perempuan, tidak hanya sebagai salah satu identitas sebagai perempuan tetapi memiliki nilai tersendiri baik dari segi biologik. Psikologik, psikoseksual, maupun psikososial. Hal ini juga dikuatkan oleh Taylor bahwa kehilangan payudara akan mengubah penampilan fisik penderita dan dapat berpengaruh pada cara pandangnya terhadap gambaran tubuh. Perempuan merasa minder, terabaikan, merasa tidak sempurna lagi sebagai seorang perempuan. Oleh karenanya, pendekatan holistik kanker payudara bukan hanya ditunjukkan secara langsung terhadap aspek-aspek psikiatrik kanker payudara, tidak semata dari segi biopatologik, tetapi terhadap nilai payudara bagi perempuan. Bila hal tersebut dapat dipahami maka usaha-usaha pencegahan, diagnosa dini maupun tindakan operatif yang diambil disertai dengan pendekatan individual, maka komplikasi-komplikasi psikiatrik yang timbul dapat diusahakan seminimalnya

Keberadaan penyakit yang mempengaruhi kondisi kesehatan fisik seseorang adalah salah satu aspek yang menentukan kualitas hidup seseorang.

\section{Psikologis}

Setiap penyakit fisik yang dialami seseorang tidak hanya menyerang manusia secara fisik saja, tetapi juga dapat membawa masalahmasalah bagi kondisi psikologisnya. Hal ini dapat kita lihat pada pasien penderita kanker payudara dimana ketika dokter mendiagnosis bahwa seseorang menderita penyakit berbahaya seperti kanker, secara umum ada tiga bentuk respon emosional yang bisa muncul pada pasien penyakit kronis seperti kanker payudara, yaitu penolakan, kecemaqufformathpresi Informan 4

\section{Hubungan Sosial}

Seseorang penderita kanker payudara akan mengalami perubahan-perubahan cara hidupnya. Ketidakpastian mengenai sisa usia dan risiko kematian yang ada membuat seseorang merasa bahwa hidupnya terbatas. Sikap depresi sangat wajar dimiliki oleh penderita kanker, namun ada pula yang tetap terlihat segar dan sehat karena mereka berusaha menutupi penyakitnya dari orangorang yang ada di sekitarnya dan bersikap seperti orang sehat lainnya, sambil mengusahakan program pengobatan untuk mencapai kesembuhan, tetap melakukan kegiatan atau pekerjaan yang selama ini ditekuninya dan masih memiliki hubungan positif dengan orang-orang di sekitarnya. Orang-orang seperti inilah yang biasanya memiliki kualitas hidup yang positif.

\section{Lingkungan}

Lingkungan yang kurang memberikan dukungan (kurang nyaman) pada penderita kanker payudara akan menyebabkan penurunan kualitas hidup penderita kanker payudara. Dimensi lingkungan yang meningkatkan kualitas hidup yaitu mencakup sumber finansial, Freedom, physical safety dan security, perawatan kesehatan dan sosial care, lingkungan rumah, kesempatan untuk mendapatkan berbagai informasi baru dan keterampilan, partisipasi dan kesempatan untuk melakukan rekreasi atau kegiatan yang menyenangkan, lingkungan fisik serta transportasi.

Saat penderita kanker payudara memiliki kualitas hidup yang positif dalam hidupnya maka sikap yang akan ditunjukkan oleh penderita adalah sikap-sikap positif. Mereka akan menerima dan beradaptasi dengan keadaannya serta berusaha untuk bertahan dan terus berjuang dalam mengusahakan kehidupan yang lebih baik. Mereka mungkin pernah merasa terpuruk dalam kondisi penyakit yang dideritanya, tetapi pemahaman kualitas hidup yang positif akan memacu mereka untuk tetap bisa mengaktualisasi dirinya, penderita kanker tidak menyerah dengan keterbatasan dirinya. Kondisi lingkungan yang baik turut mendukung kualitas hidup seorang penderita kanker payudara.

Penderita kanker payudara yang mampu menghadapi dan bangkit dari keterpurukan yang dialami akan mendorongnya untuk memiliki hidup yang lebih berkualitas, begitu pula sebaliknya, respon negatif dari seorang penderita kanker membuat kualitas hidupnya negatif. 
Kualitas hidup merupakan persepsi individu mengenai keadaan dirinya pada aspek fisik, psikologis, sosial dan lingkungan untuk mencapai kepuasan dalam hidupnya. Kebaikan dalam segala aspek hidup dan kepuasan seseorang akan membawanya pada hidup yang berkualitas. Kebaikan tersebut akan mendorong penderita kanker payudara untuk mencapai kehidupan yang berkualitas. Pengetahuan dan pemahaman penderita kanker payudara terhadap penyakitnya sangat memengaruhi kualitas hidupnya, karena tanpa tahu kondisinya dengan baik, penderita tidak tahu apa yang harus dilakukan atau apa yang tidak boleh dilakukan untuk meningkatkan kesehatannya.

Adanya dukungan sosial seperti dukungan emosi, dukungan penghargaan, dukungan instrumen, dukungan informasi dan dukungan jaringan sosial terbukti telah memiliki keterkaitan dengan adanya optimisme pada diri wanita penderita kanker payudara. Segala kesulitan dan kelemahan yang dihadapi subjek penderita kanker, mereka mampu bertahan dan menghadapinya sehingga mereka dapat mencapai optimisme. Hal tersebut juga tidak terlepas dari dukungan sosial yang berpengaruh terhadap kesejahteraan hidup seseorang. Penelitian Kiecolt-Glaser dan Glaser menemukan bahwa dukungan sosial memiliki hubungan dengan system imun yang lebih baik. Sistem imun yang lebih baik membuat sel kanker menjadi berkurang dan mendorong penderita kanker untuk optimis.

\section{Simpulan}

1) Kesehatan fisik penderita kanker payudara menurun karena merasakan nyeri, berdenyutdenyut pada daerah payudara, mengalami kebas, kehilangan payudara setelah dilakukan operasi atau pengangkatan. Mual, muntah, kerontokan rambut, mudah lelah, penurunan berat badan, menyebabkan penderita mengalami perubahan fisik.

2) Beban psikologis dirasakan semakin berat oleh penderita kanker payudara setelah divonis kanker payudara. Perasaan sedih, cemas, takut, kecewa, marah pada Tuhan, putus asa, hilang percaya diri, malu, stres, dan depresi menyebabkan pasien ingin bunuh diri.

3) Hubungan sosial dengan masyarakat sekitar tetap dijaga dengan baik oleh penderita kanker payudara dengan tetap mengikuti kegiatankegiatan di masyarakat. Tetapi kadang hilang rasa percaya diri jika ada pandangan miring orang-orang pada mereka.

4) Lingkungan yang tidak nyaman kurang memberikan rasa aman bagi penderita kanker payudara semakin meningkatkan stres penderita. Kekurangan finansial untuk biaya pengobatan menambah beban bagi penderita kanker payudara sehingga menurunkan kualitas hidupnya.

5) Dukungan sosial diperoleh penderita kanker payudara dari orang-orang terdekatnya seperti adik, anak, dan suami. Dukungan orang-orang terdekat membuat penderita menjadi lebih kuat menjalani hidup dan mempunyai harapan yang lebih baik pada masa yang akan datang.

SARAN

1) Bagi Institusi pendidikan

Diharapkan dengan adanya penelitian ini maka akan menambah referensi bacaan bagi mahasiswa yang ingin mengetahui lebih mendalam tentang kualitas hidup penderita kanker payudara

2) Penderita kanker payudara

(1) Mau membagikan (sharing) tentang segala sesuatu yang dialami (fisik dan psikis) pasca menderita kanker payudara kepada lingkungan-lingkungan sekitar (keluarga, teman, tenaga medis) agar tidak selalu merasa tertekan dan merasa lebih ringan dalam menjalani sakitnya tersebut.

(2) Tidak terlalu fokus terhadap penyakit yang dialami tetapi lebih kepada cara untuk membuat diri lebih nyaman (mungkin mencoba mengikuti relaksasi, konseling, dan sebagainya).

3) Kepada Keluarga

Disarankan kepada pihak keluarga terdekat (suami, anak, adik, dan lain-lain) selalu tetap memberi dukungan dalam bentuk apapun yang nantinya dapat membuat penderita kanker payudara tersebut merasa kuat. Selain itu diharapkan keluarga juga mampu membantu dengan menerima keadaan penderita kanker payudara apa adanya (terutama suami dan anak) dengan memotivasi penderita lebih kuat menghadapi dan menjalani proses pengobatan yang sedang berlangsung.

\section{Daftar Pustaka}

Melia. Hubungan antara frekuensi kemoterapi dengan status fungsional pasien kanker yang menjalani kemoterapi di RSUP Sanglah Denpasar. Bali: Fakultas Kedokteran Universitas Udayana; 2012.

Nawawi Q. Kematian akibat kanker meningkat menjadi 8,2 juta [berita di internet]. 2013 [diunduh tanggal 02 Oktober 2014]. Tersedia dari: www.health.okezone.com/read/2013/12/13/ 482/911746/kematian-akibat-kankermeningkat-menjadi-8-2-juta.

Miller G. Pencegahan dan pengobatan penyakit kanker. Cetakan Pertama. Jakarta: Prestasi Pustakakarya; 2012. 
Depkes RI, Riset kesehatan dasar tahun 2012. Jakarta: Departemen Kesehatan Republik Indonesia; 2013.

RSU dr. Pirngadi Medan. Data rekam medik RSU dr. Pirngadi Medan, jumlah penderita kanker payudara (ca mammae) tahun 2013 dan 2014. Medan: RSU dr. Pirngadi Medan; 2014.

Sari QNR. Dukungan sosial pada penderita kanker payudara di masa dewasa tengah. Jakarta : Fakultas Psikologi Universitas Gunadarma; 2012.

Wijayanti A, Fitri H. Penatalaksanaan gizi pada penderita kanker payudara. Makalah Pertemuan Ilmiah Nasional (PIN) ke-III. Semarang; 2012.

Lubis NL. Dampak intervensi kelompok cognitive behavorial therapy dan kelompok dukungan sosial dan sikap menghargai diri sendiri pada kalangan penderita kanker payudara. Makara Kesehatan, 2011; 15(2): 65-72.

Nurcahyo J. Awas bahaya kanker rahim dan kanker payudara, mengenal, mencegah dan mengobati sejak dini dua kanker pembunuh yang paling ditakuti wanita. Yogyakarta: Wahana Totalita Publsiher; 2010.

Yohana, Yovita, dan Yessica. Kehamilan dan persalinan. Edisi I (Kesatu) Jakarta: Garda Media; 2011.

Luwia MS. Problematik dan perawatan payudara. Cetakan Pertama. Jakarta: Agromedia Pustaka; 2010.

Wiknjosastro H. Ilmu kebidanan. Cetakan Pertama, Jakarta: Yayasan Pustaka Sarwono Prawirohardjo; 2010. 